\title{
EFFECT OF ORGANIC AND CONVENTIONAL PRODUCTION SYSTEMS ON THE WINTER WHEAT GRAIN QUALITY
}

\author{
Ingrida Augspole ${ }^{1}$, Anda Linina2 ${ }^{2 *}$, Anda Rutenberga-Ava ${ }^{2}$, Agrita Svarta $^{3}$, Vija Strazdina ${ }^{4}$ \\ ${ }^{I}$ Department of Chemistry, Faculty of Food Technology, Latvia University of Life Sciences and Technologies, \\ Liela iela 2, Jelgava, Latvia \\ ${ }^{2}$ Institute of Soil and Plants Research, Faculty of Agriculture, Latvia University of Life Sciences and Technologies, \\ Liela iela 2, Jelgava, Latvia, e-mail: anda.linina@llu.lv \\ ${ }^{3}$ Institute of Agronomy, Latvia University of Life Sciences and Technologies, "Selekcija”, Skriveri, Latvia \\ ${ }^{4}$ Stende Research Centre, Institute of Agricultural Resources and Economics, "Dizzemes”, Talsi, Latvia
}

\begin{abstract}
Cereal crops are cultivated worldwide in diverse environments. In Latvia wheat (Triticum aestivum L.) is the most common cereals. One of the most important wheat quality indices are gluten quantity and quality. The aim of this experiment was to assess the effect of different farming systems (organic and conventional) on wet gluten and quality of four winter wheat cultivars and one grain line. Field investigation with winter wheat cultivars 'Fredis', 'Edvins', 'Skagen', 'SW Magnific' and line '94-5-N' were carried out within the framework of value for cultivation and use of plant variety testing system (VCU) at the Research Institute of Agronomy (in Skriveri) of Latvia University of Life Sciences and Technologies, in 2017/2018. Gluten content, index and water-binding capacity were significantly $(\mathrm{p}<0.05)$ affected by the agricultural production systems and cultivars. In our trial were found statistically significant differences among agricultural production systems. Significantly lower gluten content and water binding capacity had in organic winter wheat grains, while gluten was significantly stronger, compared to the conventional. A statistically significant $(\mathrm{p}<0.01)$ positive correlation was found between winter wheat gluten content and water-binding capacity ( $\mathrm{r}=0.999)$ for both production systems. The cultivars 'Fredis' and 'Edvins' had better gluten content and water-binding capacity that make them more suitable for the organic production systems, compared to other cultivars.
\end{abstract}

Keywords: winter wheat, gluten content, gluten index, water-binding capacity

\section{Introduction}

Winter wheat (Tritticum aestivum L.) is one of significant and the most productive cereal species in Latvia used for food grain production, especially for bread preparation (Linina, Ruza, 2018). Researcher Jaskulska et al. (2018) describe that the cereal of wheat is the most important crop, next to corn, rice and soybean, is allocated for human consumption and for animal feed. They continue that after processing, grain is used for pastas, groats, flour and bread or added to other food and feed products. Husenov (2018) explains that wheat grain is rich in carbohydrates and has higher protein content than other major cereals, such as rye, maize and rice. It also contains substantial amounts of vitamins, minerals (e.g., Fe, Zn) and phytochemicals, making it a good source of nutrition. Wheat bread is an important component of human diet as a source of energy due to the high content of proteins as well as carbohydrates. Different combinations of proteins and carbohydrates in the wheat flour allow the production of different types of bread. Husenov (2018) also found that the bread making quality varies with backing technologies, type of bread as well as cultural traditions, it is not straight-forward to define the universal criteria for bread making quality.

Food wheat must be of good quality. Grain quality significantly varies depending on the various among cultivars (Linina, Ruza, 2012; Dekic et al., 2018; Litke, Gaile, 2018; Šekularac et al., 2018). Researchers Cesevičienè et al. (2009) and Kreičirova et al. (2006) in their study emphasizes that during ripening wheat needs moderate moisture and sunny and warm weather. Such circumstances secure biological maturity and acceptable technological properties of cereal.
To a large extent, cereal quality depends on the content of vitamins, antioxidants and nutritional compounds, also mineral nutrients, content of organic compounds (carbohydrates, fat and protein and its fractions) (Jaskulska et al., 2018).

Mis (2005) describe that gluten quality and quantity are important indices for technological processing of wheat. He also emphasizes that content of gluten is commonly used as a predictor of baking quality. Gluten index has frequently been used as a parameter of technological quality, having in mid that it is determined faster and requires a smaller amount of flour when compared to farinographic parameters (Oikonomou et al., 2015).

Jaskulska et al. (2018) describe that a special biological and performance function is played by protein, especially the gluten fraction. Glutenin and gliadin ensure dough elasticity and extensibility. Gluten determines elasticity, softness and cohesion of bread both fresh and after storage. The baking value of cereal and flour describes many traits, most importantly those, which characterize its protein complex (the content of total protein and wet gluten) and enzymatic complex (falling number).

Some researchers found that the value of the gluten parameter is affected by genotype and crop-years weather conditions. Temperature and precipitation of grain filling have a significant impact on the gluten content and index (Skudra, Ruža, 2016).

Curic et al. (2001) determined that gluten is capable of forming cohesive and adhesive masse, films and threedimensional networks, all essential to baking performance and gluten content increases with the amount of total protein content. Researchers emphasizes that gluten proteins can be categorized based on their solubility into gliadins (alcohol-water soluble) and 
glutenins (insoluble). Both glutenins and gliadins had impact to the properties of gluten. The glutenins provide strength and elasticity of dough, while gliadins create viscosity requirea for dough development. As defined in the trials, then the optimum ratio between gliadin and glutenin for high quality of gluten is found to be $1: 1: 1$ (Curic et al., 2001). Hussain et al. (2009) describe that sunny weather and low amount of precipitation after the postanthesis stage increases the content of gluten and protein content. Jaskulska et al. (2018) found out that nitrogen fertilisation makes a similar effect. It is closely connected with obtained grain yield and quality. Krejčirova et al. (2006) confirms that the relative low nitrogen availability in organic production systems limits cereal and plant nitrogen; that way, both are influenced by crop year weather condition and cultivar. Researcher from Lithuania Cesevičienè et al. (2009) describe that it is known that cereal grown under organic production system has lower gluten and protein content than the conventional. Therefore it is important to have cultivars well adapted to organic production system, to get good quality.

The aim of research was to assess the effect of different farming systems (organic and conventional) on wet gluten and quality of four winter wheat cultivars and one grain line.

\section{Materials and Methods}

\section{Field study}

Field experiment in conventional and organic farming systems was carried out (2017/2018) at the Research Institute of Agronomy (Latvia University of life Sciences and Technologies) in Skriveri (56 $16^{\circ} \mathrm{N}$ and $11^{\circ} 24^{\prime}$ E). Winter wheat (TriticumaestivumL.) cultivars 'Fredis', 'Edvins', '94-5-N' (all from Latvia), 'Skagen' (Germany) and 'SW Magnific' (Sweden) were sown on $27^{\text {th }}$ September (conventional) and on $2^{\text {nd }}$ October (organic) in 2017 after black fallow in four replications (rate of 500 germinating seeds per $\mathrm{m}^{2}$ ), a plot size of 16 $\mathrm{m}^{2}$, field layout - randomised.

Soilatthe site was silty clay loam/clay. Soil agrochemical characteristics were as follows: in conventional production system (CON) - organic mater $3.3 \%, \mathrm{pH} \mathrm{KCl} \mathrm{5.9,} \mathrm{in} \mathrm{organic} \mathrm{production} \mathrm{system}$ (ORG) - organic mater $2.5 \%, \mathrm{pH} \mathrm{KCl} 6.7$ and medium phosphorus and potassium content easily utilized by plants (in both production system).

In conventional production system (before sowing) plots were fertilized with complex NPK fertilizer 8:19:29 $300 \mathrm{~kg} \mathrm{ha}^{-1}$ nitrogen (N) $24 \mathrm{~kg} \mathrm{ha}^{-1}$, phosphorus (P) $57 \mathrm{~kg} \mathrm{ha}^{-1}$ and potassium (K) $87 \mathrm{~kg} \mathrm{ha}^{-1}$. The first dose of nitrogen $85 \mathrm{~kg} \mathrm{ha}^{-1}$ was given in spring at the beginning regrowth - starting of tillering (BBCH 20-25), the second time at the stem elongation (BBCH 32-35) N 60 $\mathrm{kg} \mathrm{ha}^{-1}$ and the third time - at the beginning of heading (BBCH 51-53) (40 kg ha-1). All the necessary plant protection measures were performed. Winter wheat was harvested at the growth stage GS 88-91, on $27^{\text {th }}$ July in organic and on $6^{\text {th }}$ August in conventional system. Harvested grain of each cultivar and plot was put into separate bags for analyses. The grain exceeding $14 \%$ moisture content was dried.

\section{Weather data collection}

Autumn of 2017 was long and wet. Winter was mild and favourable for good wheat overwintering. The air temperature in April 2018 was by $4.1{ }^{\circ} \mathrm{C}$ higher compared with long-term average observations. In Mai was by $5.1{ }^{\circ} \mathrm{C}$ warmer, which hat affected plant growth and development (Table 1).

Table 1

Weather conditions during the field investigation

\begin{tabular}{|c|c|c|c|}
\hline \multirow[b]{2}{*}{ Month } & 2018 & LTM* & + or-from LMT \\
\hline & \multicolumn{3}{|c|}{ Average temperature, ${ }^{\circ} \mathrm{C}$} \\
\hline April & 9.0 & 4.9 & +4.1 \\
\hline May & 16.5 & 11.4 & +5.1 \\
\hline June & 16.9 & 15.0 & +1.9 \\
\hline July & 20.6 & 16.6 & +4.0 \\
\hline \multirow{2}{*}{ Average } & 15.8 & 12.0 & +3.8 \\
\hline & \multicolumn{3}{|c|}{ Sum of precipitation, $\mathrm{mm}$} \\
\hline April & 43.3 & 47.0 & -3.7 \\
\hline May & 23.7 & 55.0 & -31.3 \\
\hline June & 36.1 & 69.0 & -32.9 \\
\hline July & 61.6 & 88.0 & -26.4 \\
\hline Sum & 164.7 & 259.0 & -94.3 \\
\hline
\end{tabular}

In June average daily temperature was by $1.9{ }^{\circ} \mathrm{C}$ which contributed to the accumulation of gluten and protein content. Temperature in the grain filling period (July), which is particularly important for grain quality formation, was by $4.0{ }^{\circ} \mathrm{C}$ warmer than the long- term average mean data. Precipitation in 2018 was by $94 \mathrm{~mm}$ less than long-term means data.

\section{Technological properties of wheat}

The winter wheat grain wet gluten index, gluten content and water-binding capacity were determined at the Latvia University of Life Sciences and Technologies, Institute of Soil and Plants Research in the Grain and Seed Research Laboratory according to Perten using Standard ICC 155.

Laboratory Mill 3100 (Perten Instruments, Sweeden) was using for grains milled to wholemeal at a particle size of $8.0 \mathrm{~mm}$. Wet gluten was washed from wholemeal by an automatic gluten washing equipment (Glutomatic) and centrifuged through a specially constructed sieve under standardized conditions. The weight of the wet gluten was the weight of the gluten was passed.

The weight of the wet gluten was the weight of the gluten was passed. The total wet gluten was then dried (Glutork 2020) and weighed. The difference between the weights of total wet gluten and total dry gluten was calculated, which gave the weight of water bound in the wet gluten and this was water-binding capacity. Total wet gluten contents were expressed as percentage. The gluten index is the ratio of the wet gluten on the sieve (after gluten centrifugation) to the total wet gluten.

\section{Statistical analysis}

Two-factor analysis was used to determine significant differences. The Fisher's criterion was applied to 
estimate the effects of production systems and cultivars. Component of variance ANOVA for each Quality characteristic was expressed as percentage to illustrate the relative impact of each source to the total variance. One-factor of variance by Fisher's criteria and least significant difference $\left(\mathrm{LSD}_{0.05}\right)$ were applied toassess the effect of conventional and organic production system to each of cultivar separately. Significance of the gluten content and quality between conventional and organic production systems determined by t-test: Two Sample Assuming Unequal variance. Correlation analysis between wet gluten, gluten index and waterbinding capacity was also carried out.

\section{Results and Discussion}

Winter wheat grain gluten content, gluten index and water-binding capacity were significantly $(p<0.05)$ affected by agricultural production system and cultivars. In conventional system, mean gluten content was $30.2 \%$ $(\mathrm{V}=8.0 \%)$ and it was higher than in organic system $21.8 \%(\mathrm{~V}=7.4 \%)$. The least variation of the grain gluten index (average 86.1) was noticed in the organic production system, with coefficient of variation of $10.1 \%$.

Table 2

Winter wheat grain quality indices mean for all cultivars

\begin{tabular}{lcccc}
\hline Quality indices & $\begin{array}{c}\text { Mean } \\
\text { 土standard } \\
\text { error }\end{array}$ & min & max & V\% \\
\hline \multicolumn{5}{c}{ Conventional production system (CON) } \\
\hline WG, $\%$ & $30.2 \pm 1.1$ & 27.3 & 33.5 & 8.0 \\
GI & $67.5 \pm 7.9$ & 47.0 & 86.0 & 26.0 \\
WB, $\%$ & $202.1 \pm 10.9$ & 173.0 & 235.0 & 12.0 \\
\hline \multicolumn{5}{c}{ Organic production system (ORG) } \\
\hline WG, $\%$ & $21.8 \pm 0.7$ & 20.3 & 24.3 & 7.4 \\
GI & $86.1 \pm 7.9$ & 71.0 & 93.0 & 10.1 \\
WB $\%$ & $117.8 \pm 7.2$ & 103.0 & 143.0 & 13.7 \\
\hline
\end{tabular}

WG-gluten content, \%; GI-gluten index,

WB-water binding capacity, $\%$.

Scientists Mikos and Podolska (2012) from Polish reported that Gluten content is an important indicator of grain quality for the bread making industry. In Latvia, grain processing companies classify wet gluten into four classes. The first class is called to as very good with wet gluten content above $28.0 \%$. The Second class is called to as good with gluten above $26.0 \%$. In turn the third class is considered when wet gluten is above $24.0 \%$ and the fourth class is called to as low - containing wet gluten below $20.0 \%$. The grain analyses in our investigation suggested that gluten content in conventionally grown grains was significantly $(\mathrm{p}<0.05)$ higher than in organically grown grains.

The gluten content in conventional production system ranged from $27.3 \%$ (line '94-5-N') to $33.5 \%$ ('Fredis') (Figure 1). Gluten content of harvested grains corresponded to criterion stated for food wheat (first and second class). The differences in gluten content among different samples can be explain by genetic variation in the winter wheat cultivars.

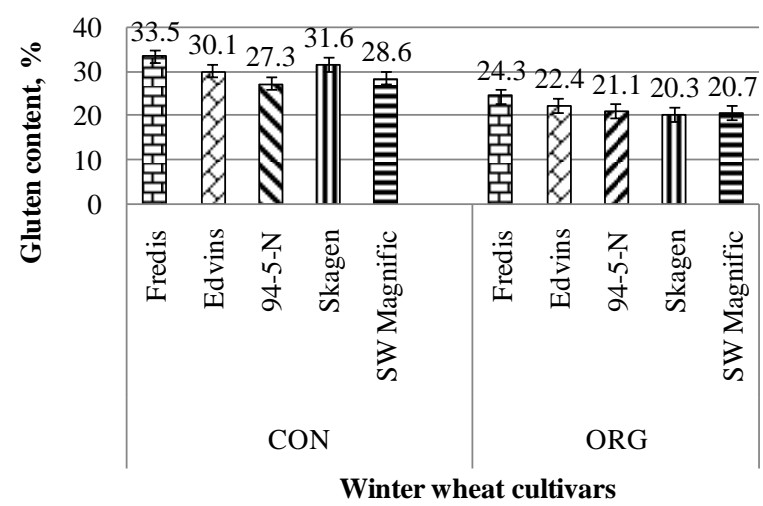

Figure 1. Winter wheat wholemeal gluten content in conventional (CON) and organic (ORG) production systems

Cesevičienè and co-authors (2012) in Dotnuva (Lithuania) found similar results (2012). Scientists concluded that warmer weather was more beneficial for the formation of protein (also gluten content) in winter wheat grains. Litke and Gaile (2018) reported that gluten content in winter wheat cultivar 'Skagen' in conventional system was from $14.7 \%$ (without nitrogen fertilization N0) to $25.9 \%$ (N180). The gluten content in organic production system ranged from $20.3 \%$ ('Skagen') to $24.3 \%$ ('Fredis') (Figure 1). Gluten content corresponds to food grain demands (fourth class). Konvalina et al. (2011) reported that gluten content in organic farming was from 18.1 to $23.6 \%$ in winter wheat cultivars grown in Czech Republic, because plants lack nutrients. These results agree with the findings of our study.

Gluten index is an indicator of gluten strength (Šekularac et al., 2018). Weak gluten has a gluten index value $<30$, the normal gluten index from 30 to 80 and strong gluten index >80 (Oikonomou et al., 2015). In both production systems gluten index varied from normal to strong (Figure 2). The highest gluten index showed 'Skagen' (in CON 86.0 units) and 'Edvins' (in ORG 93 units), while the lowest gluten index was measured for line '94-5-N' (in CON 52.8 units, in ORG 71.4 units). The gluten index in organic production system wassignificantly $(p<0.05)$ higher compared to conventional. With the decrease in gluten content (ORG), the gluten index increased (Cesevičienè et al., 2012). Similar results obtained in our study.

Vaiciulute-Funk et al. (2015) showed that the gluten content (for six cultivars of winter wheat) was from $13.8 \%$ to $32.8 \%$ and gluten index from 11 to 94 units. Vaiciulute-Funk et al. (2015) also confirmed that the gluten index and gluten content of different winter wheat cultivars may vary in the same growing conditions, similar results we obtained in our experiment too. 


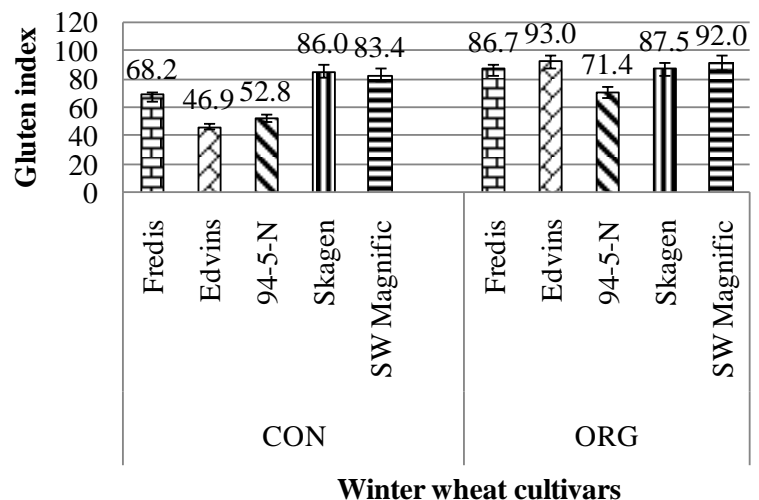

Figure 2. Winter wheat wholemeal gluten index in conventional (CON) and organic (ORG) production systems

Water-binding capacity is the ability of the gluten to attract and retain a certain amount of water. Water-binding capacity has significant influence on the rheological properties of the dough (Mis, 2005). In our investigation, water-binding capacity in organic production system was from $107 \%$ ('SW Magnific') to $143 \%$ ('Fredis'), and in conventional from $173 \%$ ('94-5-N') to 235\% ('Fredis') (Figure 3). Water binding in wet gluten depended on cultivars.

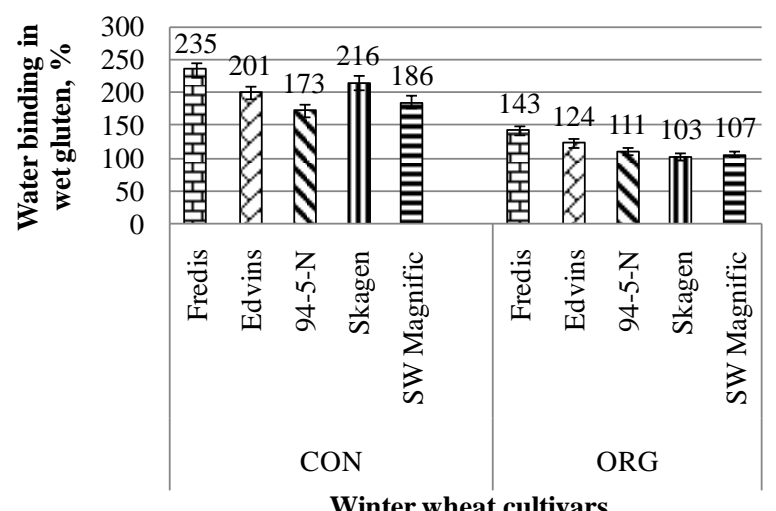

Figure 3. Winter wheat wholemeal water-binding capacity in conventional (CON) and organic (ORG) production systems

Data in Figure 1, 3 present a significant positive correlation was found between gluten content and waterbinding capacity in both production systems: CON $\mathrm{r}=0.999, \quad \mathrm{R}^{2}=0.996, \quad$ a regression equation $\mathrm{y}=1.532 \mathrm{x}+25.61$; ORG $\mathrm{r}=0.999, \mathrm{R}^{2}=0.893$, a regression equation $\mathrm{y}=0.967 \mathrm{x}+18.87$. Cultivars 'Fredis' and 'Edvins' had better gluten content and water-binding capacity that make them more suitable for the organic production systems, compared to other cultivars (Figure 1, 3). Researchers Sterna et al. (2017) reported that the choice of cultivar is a critical factor in efficient organic farming.

The production system in investigation year, cultivars and production system $\times$ cultivar interaction had a significant $(\mathrm{p}<0.05)$ impact on the gluten content, gluten index and water-binding capacity (Table 3 ).

Table 3

Impact factors of winter wheat quality indices

\begin{tabular}{lccc}
\hline Source of variation & WG & GI & WB \\
\hline Production system & $83.1^{*}$ & $35.7^{*}$ & $83.1^{*}$ \\
$\begin{array}{l}\text { Cultivar } \\
\text { Production }\end{array}$ & $12.5^{*}$ & $39.4^{*}$ & $12.5^{*}$ \\
system $\times$ cultivar & $3.4^{*}$ & $23.6^{*}$ & $3.4^{*}$ \\
\hline
\end{tabular}

WG-gluten content, \%; GI-gluten index,

WB-water binding capacity, \%. *significant $(\mathrm{p}<0.05)$

Wet gluten and water-binding capacity were most affected by production system $(83.1 \%)$ but influence of a cultivar was also remarkable $(12.5 \%)$, while the influence production system $\times$ cultivar was small $3.4 \%$ Our results showed that gluten index mostly depends on cultivar (39.4\%) and production system $(35.7 \%)$ and less on factor interaction $(23.6 \%)$.

\section{Conclusions}

Winter wheat gluten content, gluten index and water binding capacity were significantly $(p<0.05)$ affected by the agricultural production systems and cultivars. In our trial, statistically significant differences were found between agricultural production systems. Organic winter wheat grain had significantly $(p<0.05)$ lower gluten content and water-binding capacity, while gluten was significantly stronger, compared with the conventional. Cultivars 'Fredis' and 'Edvins' had better gluten content and water-binding capacity that make them more suitable for the organic production system, compared to other cultivars. This paper analyses only the results of one year, the trial will be continued.

\section{References}

1. Cesevičienè J., Slepetiene A., Leistrumaite A., Ruzgas V. (2012) Effects of organic and conventional production systems and cultivars on winter wheat technological properties. Journal of the Science of Food and Agriculture, Vol. 92(14), p. 2811-2818.

2. Cesevičienè J., Leistrumaite A., Paplauskiene V. (2009) Grain yield and quality of winter wheat varieties in organic agriculture. Agronomy Research, Vol. 7(1), p. 217-223.

3. Curic D., Karlovič D., Tušak D., Petrovic B., Dugum J. (2001) Gluten as a standard of wheat flour quality. Food Technology and Biotehnology, Vol. 39, p. 355-361.

4. Dekic V., Miliovojevic J., Popovic V., Brankovic S., Terzic D., Ugrenovic V. (2018). Effects of fertilization on production traits of winter wheat. In: International GEA conference: Green room session. Conference proceedings. Podgorica, Montenegro, p. 25-32.

5. Husenov B. (2018) Towards an impact on food security for Tajikistan. Improved wheat grain and seed quality through plant breeding as a key. Doctoral Thesis No. 2018:5. Faculty of Landscape Architecture, Horticulture and Crop Production Science Department of Plant Breeding Alnarp, $60 \mathrm{p}$.

6. Hussain A., Larsson H., Kuktaite R., Prieto-Linde M.L., Johansson E. (2009) Protein content and composition in organically grown wheat: influence of genotype. 
Agronomy Research, Vol. 7 (Special issue II), p. $599-605$.

7. Jaskulska I., Jaskulski D., Gałezewski L., Knapowski T. (2018) Mineral composition and baking value of the winter wheatGrain under varied environmental and agronomic conditions. Journal of Chemistry, Vol. 2018, p. 1-7.

8. Konvalina P., Stehno Z., Capuchova I., Moudry J. (2011) Wheat growing and quality in organing farming. In: Open Access books Research in Organing Farming, p. $105-122$.

9. Krejčirova L., Capouchova I., Petr J., Bicanova E., Kvapil R. (2006) Protein composition and quality of winter wheat from organic and conventional farming. Zemdirbyste-Agriculture, Vol. 93(4), p. 285-296.

10. Linina A., Ruza A. (2018) The influence of cultivar, weather conditions and nitrogen fertilizer on winter wheat grain yield. Agronomy Research, Vol. 16(1), p. $147-156$.

11. Linina A., Ruza A. (2012) Cultivar and nitrogen fertilizer effects on fresh and stored winter wheat grain quality indices. In: Proceedings of the Latvian Academy of Sciences, Section B: Natural, Exact and Applied science. Vol. 66(4/5), p. 177-184.

12. Litke L., Gaile Z. (2018) Effect of nitrogen fertilization on winter wheat yield and yield quality. Agronomy Research, Vol. 16(2), p. 500-509.

13. Mašauskienè A., Cesevičienè J. (2007) Tręšimo azoto trąšomis ir oro sąlygų poveikis žieminių kviečiu glitimo savybėms grūdų laikymo metu (Impact of nitrogen fertilization and weather conditions on winter wheat gluten properties during the grain storage period). Maisto Chemija ir Technologija, Vol. 41(issue 1), p. 46-53.
14. Mikos M., Podolska G. (2012) Bread-making quality of old common bread (Triticum aestivum ssp.vulgare L.) and spelt (Triticum aestivum ssp. spelta L.) wheat cultivars. Journal of Food, Agriculture and Environment, Vol. 10(3, 4), p. 221-224.

15. Mis A. (2005) Influence of chosen factors on water absorption and rheological properties of gluten of bread wheat (Triticuma estivum L), Acta Agrophysica, Vol. 128(8), p. 1-12.

16. Oikonomou N. A., Bakalis S., Rahman M. S., Krokida M. K (2015) Gluten index for wheat products: main variables in affecting the value and nonlinear regression model. International Journal of Food Properties, Vol. 18, p. $1-11$.

17. Šekularac A., Torbica A., Živančev D. (2018) The influence of wheat genotype and environmental factors on gluten index and the possibility of its use as bread quality predictor. Genetica, Vol. 50(1), p. 85-93.

18. Skudra I., Ruža A. (2016) Winter wheat grain baking quality depending on environmental conditions and fertilizer. Agronomy Research, Vol. 14 (2), p. 1460-1465.

19. Sterna V., Strazdina V., Kronberga A., Sturite I., Assveen M. (2017). Evaluation of the composition of winter wheat grains grown in Latvia and Norway. AGROFOR International Journal, Vol. 2(I3), p. $157-164$.

20. Vaiciulute-Funk L., Joudeikiene G., Bartkiene E. (2015) The relationship between wheat baking properties, specific high molecular weight glutenin components and characteristic of varieties. Zemdirbyste-Agriculture, Vol. 102(2), p. 229-238. 